\title{
DETERMINANTS OF OFFICE RENT WITH SPECIAL REFERENCE TO THE CITY OF KANDY
}

Dissertation submitted to the University of Sri Jayewardenepura as a partial fulfillment for the requirements of the final examination of the M.Sc. in Real Estate Management and Valuation Degree

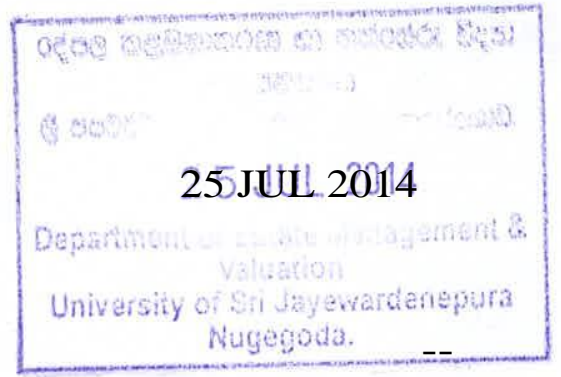

Full Name

Examinatiion No

Registration No

Department

University

First submission (for evaluation)

Secomd submissiom ((comrectted ffimall report): $244^{\text {th }}$ Jully 2014
: Anuradha Senevirathne

: REMV / 85

: GS / M.Sc I REMV // 3773 / 09

: Estate Management and Valuation

: University of Shi Jayewaurdenepura

: $28^{\text {th }}$ Fedbruary, 2014

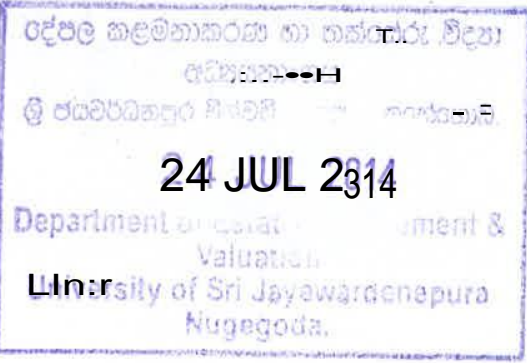


The work described in this dissertation was carried out under the supervision of Prof. R.G. Ariyawansa, Professor of Department of Estate Management \& Valuation and any report on this has not been submitted in whole or in part to any university or any other institute for another degree / examination or any other purpose.

Full Name

Examination No

Signature of the Candidate

Date
: Anuradha Senevirathne

: REMV / 85

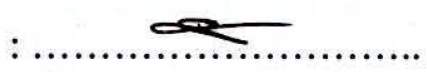

$: 24.07 .2014$ 
Hereby, I certify that Mr. Anuradha Senevirathne, (GS / M.SC / REMV 3773 / 09) duly completed the research titled "Determinants of Office Rent with special reference to the City of Kandy" under my supervision and also it is declared that, this final report has been completed according to the instructions and suggestions made by the board of examiners.

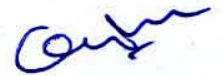

Signature of the supervisor

Signature of the $2^{\text {nd }}$ examiner

Signature and the official stamp of the Head 


\section{ACKNOWLEDGEMENTS}

First I would like to express my sincere gratitude and appreciation to my supervisor, Prof. R.G. Ariyawansa of Department of Estate Management \& Valuation, and University of Sri Jayewardenepura without whose invaluable guidance and support I could not complete this study.

I would like to thank for the Head of the Department of Estate Management \& Valuation, University of Sri Jayewardenepura and Mrs. Janakei Edirisinghe and Mrs. N.C. Wickramaarachchi, other Lecturers of Department of Estate Management \& Valuation for their valuable comments and support to improve my knowledge in the field of real estate management and valuation.

I sincerely thank to my employer, Mr. P.W. Senarathne, Mr. R.M.R.N. Rajakaruna former Chief Valuers and current Chief Valuer Mr. E. Dayasena, Government Valuation Department and Regional Valuer Central Region (I) Mr. W.M.H.G. Heenbanda who have made the necessary arrangements for me to undertake the M.Sc. in Real Estate Management \& Valuation degree course.

I would like to thank to Dr. B.M. Wasantha Athukorala Senior Lecturer of Department of Economics and Statistics, University of Peradeniya who kindly support to data analysis in this study.

I would like to present my thank to my friend Laxshmi Ekanayake for her great friendship, patience and support that motivated me all the time, I offer my sincere thank to her.

To my mum, thanks for your encouragement and being with me whenever I need. You are loved deeply.

Finally, I would like to acknowledge with gratitude my wife, Inoka, and my two kids, Basitha and Sanulya, who have, as always, so willingly sacrificed their "quality time" with me so I could commit a sizeable portion of the scarce resources of energy, attention and time to the activity of doing this thesis. 


\begin{abstract}
When goes with this study, the Real Estate for Office use was focused. An office is an architectural and design phenomenon; whether it is a small office such as a bench in the corner of a small business of extremely small size, through entire floors of buildings, up to and including massive buildings dedicated entirely to one company.

Commercial real estate markets, however, are characterized by spatial constraints, extensive product differentiation and information asymmetries that give rise to economically fragmented markets. A number of previous studies have demonstrated that such distinct submarkets do exist within urban office markets. The highly localized patterns of occupancy and rental rate determination found in these studies are indicative of market fragmentation.
\end{abstract}

This thesis analyzes determinants of variations in office rents in the city of Kandy. The theoretical background of this study is related to the hedonic methodology, which is extensively applied for explaining price or rental price variations of the office units. Given this theoretical framework, hedonic regression model is utilized for the estimation of hedonic price indices by using the cross sectional data of the office market in Kandy as for the year of 2013 .

The study uses data, obtained from rating cards maintained by the Government Valuation Department for office properties and through a field survey. Out of 23 wards from Kandy Municipal Council area 06 wards has been selected considering the high concentration of population, labor force, and office activities. Out of 405 total number of office units, 198 units are selected as the sample of this study under systematic sampling and purposive sampling method.

The actual rental values have been applied as dependant variable along with 27 independent variables as predictors to run multiple regression analysis. The OLS estimation has been applied using SPSS for the analysis. The result generated from the analysis indicated that the floor area or size of the building, age of the building, availability of parking facilities and availability of lift facilities were among the significant predictors of office rent.

Finding of this study evidenced that Hedonic regression model is a quantifiable and justifiable method for office rent predictions, hence it is recommended to apply this technique for rating rent valuation of office properties by considering further improved rent models appropriate for different geographical areas. Consequently, delays on implementation of rent revisions could be minimized.

This study which identifies and quantifies the rent determinants on office properties recognizes the importance of study on local office markets and also it would be useful for the values to make aware of influence of significant attributes associated with office property on its rental value. Moreover, the results suggest that the capability of application of Hedonic Price Model for property valuation practices in the country as a rent prediction tool which would definitely accelerate the process involved with valuation and secure its consistency than it is done manually by professionals. 


\section{ABBREVIATIONS}

$\begin{array}{ll}\text { AAGR } & \text { - Average Annual Growth Rate } \\ \text { CBD } & \text { - Central Business District } \\ \text { CPI } & \text { - Consumer Price Index } \\ \text { E/L } & \text { - Electricity } \\ \text { KMC } & \text { - Kandy Municipal Council } \\ \text { HPM } & \text { - Hedonic Price Model } \\ \text { OLS } & \text { - Ordinary Least Squares } \\ \text { UDA } & \text { - Urban Development Authority } \\ \text { VIF } & \text { - Variation Inflation Facator } \\ \text { W/S } & \text { - Water Service } \\ \text { Tp } & \text { - Telephone }\end{array}$




\section{Table of Contents}

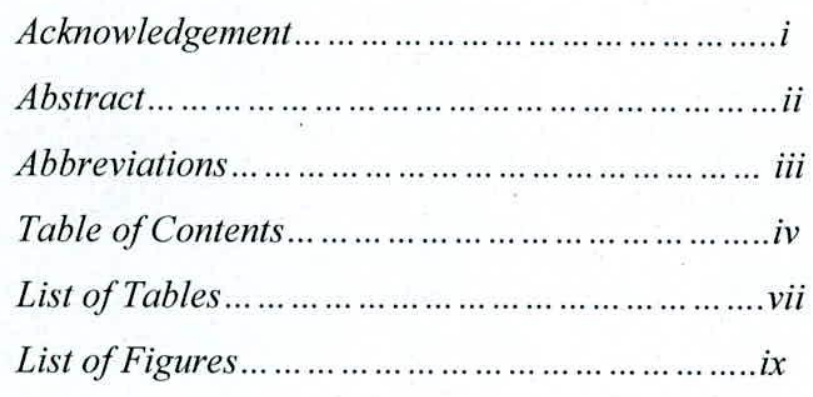

Contents

Pages

CHAPTER ONE - Introduction

$01-07$

1.1. Background of the Study 01

1.2. Research Problem 05

1.3. Objectives of the Study 05

1.3.1. General Objective 05

1.3.2. Specific Objectives 05

1.4. Significance of the Study 05

1.5. Thesis structure 06

$\begin{array}{ll}\text { CHAPTER TWO - Literature Review } & 08 \text { - } 38\end{array}$

2.1. General Characteristics 09

2.1.1. Physical Characteristics 09

2.1.2. Location Factors $\quad 14$

2.2. Special Characteristics 16

2.2.1. Environmental Factors 21

2.2.2. Location Factors $\quad 22$

2.3. Transfer (Lease) Characteristics 22

2.4. Hedonic Model 23

2.5. Summary 37

CHAPTER THREE - Research Design $\quad 39$ - 50

3.1. Introduction 39

3.2. Research Design 39

3.3. Research Process 40

3.4. Identification of Variables 42

$\begin{array}{ll}\text { 3.5. Empirical Model } & 47\end{array}$ 
3.6. Population and Sample

3.7. Questionnaire design, Survey Instrument and Data collection Procedure

CHAPTER FOUR - Background of the Study Area

4.1. Introduction

4.2. Frequently Visited Places by Foreign and Domestic

Tourists/Visitors in the Kandy 52

4.3. Commercial Activities in Kandy 55

4.4. Demographic Profile 55

4.4. Distribution of Building Units 58

4.5. Land Use Profile 59

CHAPTER FIVE - Data Analysis $61-96$

5.1. Introduction 61

5.2. Comparison of Office Rent Determinants 62

5.2.1. Age of the Building 62

5.2.2. Floor Finish 63

5.2.3. Wall Covering 63

5.2.4. Reception Area 64

5.2.5. Zoning 65

5.2.6. Type of Building 66

5.2.7. Building Appearance 66

5.2.8. Air Condition Facilities 67

5.2.9. Staircase 68

5.2.10. Lift Facility 69

5.2.11. Security System 69

5.2.12. Facilities for Customers 70

$\begin{array}{ll}\text { 5.2.13. Provision for disable peoples } & 71\end{array}$

5.2.14. Garden of the office $\quad 72$

5.2.15. Floor Area $\quad 72$

5.2.16. Vertical Location of the office 73

5.2.17. Total Number of floors of the building $\quad 74$

5.2.18. Attached Bath Room \& Toilet 75

5.2.19. Distance to Town Centre 76

$\begin{array}{ll}\text { 5.2.20. Parking } & 76\end{array}$ 
5.2.21. Historical City Band

5.2.22. Scenic View 78

5.2.23. Heritage Control \& Architectural Design 79

$\begin{array}{ll}\text { 5.2.24. Weather/Climate } & 79\end{array}$

$\begin{array}{ll}\text { 5.2.25. Cultural Factors } & 81\end{array}$

$\begin{array}{ll}\text { 5.2.26. Topography } & 82\end{array}$

5.3. Estimation Results 83

5.3.1. Validation of Measurement Properties $\quad 84$

5.3.2. Tests of Normality $\quad 84$

$\begin{array}{ll}\text { 5.3.3. Normality Test Results } & 88\end{array}$

5.4. Hypothesis Testing $\quad 90$

5.5. Estimation results for Model 91

CHAPTER SIX - Conclusions \& Recommendations 97 - 102

$\begin{array}{ll}\text { 6.1. Conclusion } & 97\end{array}$

$\begin{array}{ll}\text { 6.2. Recommendations } & 102\end{array}$ 


\section{List of Tables}

Table

Pages

Table 1.1. Average office rent in different district in Sri Lanka 3

Table 3.1. Variable Description 45

Table 3.2. Office units selected for the population. 48

Table 3.3. Distribution of the Sample among Selected Wards 49

Table 4.1. Historical Growth of Population In Kandy Municipal Area 56 $1871-2011$

Table 4.2. Population Distribution by Wards -Kandy Municipal Area 200157 And 2011

Table 4.3. Distribution of buildings of Architectural value by street 58

Table 4.4. Distribution of buildings of Architectural value by streets 59

Table 4.5. Existing Land Use Kandy Municipal Council Area - $2013 \quad 59$

Table.4.6. The Zoning of land for different uses 2002 - 2016 60

Table 5.1. Age of the Building 62

Table 5.2. Floor Finish 63

Table 5.3. Wall Covering 64

Table 5.4. Reception Area 64

Table 5.5. Zoning 65

Table 5.6. Type of building $\quad 66$

$\begin{array}{lll}\text { Table 5.7. Building Appearance } & 67\end{array}$

$\begin{array}{lll}\text { Table 5.8. Air Condition Facilities } & 67\end{array}$

$\begin{array}{lll}\text { Table 5.9. } & \text { Staircase } & 68\end{array}$

$\begin{array}{lll}\text { Table 5.10. Lift Facility } & 69\end{array}$

$\begin{array}{lll}\text { Table 5.11. Security System } & 70\end{array}$

Table 5.12. Facilities for Customers 70

Table 5.13. Provision for disable peoples 71

Table 5.14. Garden of the office 72

Table 5.15. Floor Area of office 73

Table 5.16. Vertical Location 73

Table 5.17. Number of floors of office building $\quad 74$

Table 5.18. Attached Bath Room and Toilet 75

Table 5.19. Distance to Town centre 76 
$\begin{array}{lll}\text { Table 5.20. } & \text { Parking } & 76\end{array}$

$\begin{array}{lll}\text { Table 5.21. Historical City Band } & 77\end{array}$

$\begin{array}{lll}\text { Table 5.22. Scenic View } & 78\end{array}$

Table 5.23. Heritage Control \& Architectural Design 79

Table 5.24. Weather/Climate 80

$\begin{array}{lll}\text { Table 5.25. Cultural Factors } & 81\end{array}$

Table 5.26. Topography $\quad 82$

Table 5.27. Estimation Results $\quad 83$

$\begin{array}{lll}\text { Table 5.28. Tests of Normality } & 85\end{array}$

Table 5.29. Test of Normality Syntax 86

Table 5.30. Model Summary 86

$\begin{array}{lll}\text { Table 5.31. ANOVA Table } & 87\end{array}$

$\begin{array}{lll}\text { Table 5.32. Normality Test Results } & 87\end{array}$

Table 5.3.1. Normality Test Model Summary $\quad 89$

$\begin{array}{lll}\text { Table 5.3.2. ANOVA Normality Test } & 89\end{array}$

Table 5.3.3. Results of hypothesis testing for City Image and Office Rent 90

Table 5.5.1. Estimation results for Model 92

Table 5.5.2. ANOVA Table Model $1 \quad 94$

$\begin{array}{lll}\text { Table 5.5.3. Coefficients } & 94\end{array}$

Table 5.5.4. Co linearity Statistics 95

Table 5.5.5. ANOVA Table Model 2 96 


\section{List of Figures}

Figure

Pages

Figure 3.1. Theoretical frame works 40

Figure 3.2. Conceptual Framework 41

Figure 4.1. Location Map $\quad 52$

Figure 5.1. Age of the building $\quad 62$

$\begin{array}{lll}\text { Figure 5.2. Floor Finish } & 63\end{array}$

$\begin{array}{lll}\text { Figure 5.3. Wall Covering } & 64\end{array}$

Figure 5.4. Reception Area 65

Figure 5.5. Zoning 65

Figure 5.6. Type of building $\quad 66$

$\begin{array}{lll}\text { Figure 5.7. Building Appearance } & 67\end{array}$

Figure 5.8. Air Condition Facilities 68

$\begin{array}{lll}\text { Figure 5.9. Staircase } & 68\end{array}$

$\begin{array}{lll}\text { Figure 5.10. Lift Facility } & 69\end{array}$

$\begin{array}{lll}\text { Figure 5.11. Security System } & 70\end{array}$

Figure 5.12. Facilities for Customers 71

$\begin{array}{lll}\text { Figure 5.13. Provision for disable peoples } & 71\end{array}$

$\begin{array}{lll}\text { Figure 5.14. Garden of the office } & 72\end{array}$

Figure 5.15. Floor Area of the office 73

Figure 5.16. Vertical Location of the Building 74

$\begin{array}{lll}\text { Figure 5.17. Total Number of floors } & 75\end{array}$

$\begin{array}{lll}\text { Figure 5.18. Attached Bath Room and Toilet } & 75\end{array}$

Figure 5.19. Distance to Town Centre 76

$\begin{array}{lll}\text { Figure 5.20. Parking } & 77\end{array}$

$\begin{array}{lll}\text { Figure 5.21. Historical City Band } & 78\end{array}$

$\begin{array}{lll}\text { Figure 5.22. Scenic View } & 79\end{array}$

Figure 5.23. Heritages Control \& Architectural Design 80

Figure 5.24. Weather/Climate 81

Figure 5.25. Cultural Factors 82

Figure 5.26. Topography 83

$\begin{array}{ll}\text { Figure 5.3.1. Normality Test } & 88\end{array}$

Figure 5.5.1. Dependent Variable 93 
Figure

Pages

Figure 5.5.2. Regression Standardized Residual 


\section{CHAPTER ONE}

\section{Introduction}

\subsection{Background of the study}

Infinite wants of human beings originate with the limited needs. According this is very common for Real Estates which can be defined as "Property consisting of land and the buildings on it, along with its natural resources such as crops, minerals, or water; immovable property of this nature (Eda Ustaouglu, 2003). Real properties are overvalued when it goes beyond the limits of the bond of natural and manmade creature. The legal interest gives it another position called "Real Property" creating a new value than previously.

Dunse et al ( 2003) stated that, Depending on the nature of the property, an owner of property has the right to consume, alter, share, redefine, rent, mortgage, pawn, sell, exchange, transfer, give away or destroy it, or to exclude others from doing these things, as well as perhaps to abandon it; whereas regardless of the nature of the property, the owner thereof has the right to properly use it (as a durable, mean or factor, or whatever), or at the very least exclusively keep it. . Accordingly the usages of these Real Properties, they can be distinguished basically from Residential, Commercial, and Office as well as Factories, Agriculture and many more. These can be existed with Freehold or Leasehold interests. Each of these has its own value. In the real property market, the problem of determining value is more complex. The reason is related to the heterogeneity of the market. Each property possesses specific characteristics or attributes such as location and physical characteristics of the property. The value of each property varies widely and systematically with these characteristics.

When goes with this study, the Real Estate for Office use has to be focused. An office is an architectural and design phenomenon; whether it is a small office such as a bench in the corner of a small business of extremely small size (see small office/home office), through entire floors of buildings, up to and including massive buildings dedicated entirely to one company. In modern terms an office usually refers to the location where white-collar workers are employed (Delik Pekdemir, 2009). While the interest for real property is either freehold or leasehold most of the Office uses are leasehold due to the inheritance of this usage. Considering the leasehold property, 
both landlords and tenants are interested in the 'rental price' and the 'rental value' of the property. Ring, $(1972,161)$ has expressed the Rent has been defined as a "definite periodic return, in terms of money or other provisions, for the use of property". Based on this definition, it can be stated that rental price of the property is important as it indicates the amount of rental payment that must be paid by tenants and the amount of rental income that will be received by landlords. Rental price is primarily determined in the market due to the supply and demand relationship. Expectations about future interest rates are major fundamentals underlying the pricing of bonds with various contract terms, resulting in a clearly observable term structure of interest rates. A similar phenomenon is likely to exist in the rental market, where expectations about the future development of spot rents would result in different rent levels for lease contracts with different lengths of tenure. If observable, the term structure of leases should reveal the expectations in the rental market, thus supplying a true market fundamental for the valuation of portfolios of leases, i.e. property values. Furthermore, the rental term structure is likely to indicate rental market turning points, and thus become a lead for turns of the property cycle.

The determining factors of office rental values are researched and documented by empirical studies in different countries. (Greer and Farrell, 1993) stated that a property's rental value is related to "its capacity to satisfy the needs of prospective tenants and its locational advantages relative to those of competing rental properties". In other words, the ability of a property to satisfy a tenant need is generally reflected by the level of rental income that the property is capable of generating. This ability is referred to as property's 'functional utility' and is related to the measure of its productivity. In Greer and Farrell's explanation, "both natural and manmade features contribute to productivity, as does location" (Greer and Farrell, 1993: 89). Hence, property's ability to command rents is basically related to its Physical or general and Special characteristics.

Commercial property has an important role in real estate markets. Ring (1972) stated that commercial property as a property-related issue affects everyone in the sense that it shapes the built environment. Furthermore, the importance can be related to three different factors: First, as a factor of production, commercial property provides the space to house the activities of business and industry. Second, as a financial asset, 